\title{
Electrocardiography Knowledge Levels of Pediatric Physician Residents and Interns and the Influencing Factors
}

\section{Pediatri Asistanları ile İntörnlerin Elektrokardiyografi Bilgi Düzeyi ve Etkileyen Faktörler}

\author{
Gülhadiye Avcu1, Ertürk Levent2 \\ ${ }^{1}$ Ege University Faculty of Medicine, Department of Child Health and Diseases, Izmir, Turkey \\ 2Ege University Faculty of Medicine, Department of Pediatric Cardiology, Izmir, Turkey
}

\begin{abstract}
Aim: Electrocardiography (ECG) is the most commonly used method for determining the cardiovascular disease. The aim of this study was to assess the ECG knowledge levels of pediatric residents and interns and to determine that how often the ECG education should be given in medical education.

Materials and Methods: This study was carried out in the Ege University Medical Faculty, Children's Hospital of within 2009-2010 education-year. Twenty four residents and 35 rotating interns were included. A test consisting of 20 ECG patterns was applied to both groups. After this pre-evaluation, electrocardiology training was provided for both groups by a lecturer from pediatric cardiology department. After the training, the same test was presented to participants at one month and at one year.

Results: Of the residents $16(69.5 \%)$ were females and 7 (30.5\%) were males. Seventeen $(73.9 \%)$ of the assistants were Turkish citizens, $6(26.1 \%)$ were foreign nationals. Three $(13 \%)$ of the assistants were on their first year of residency, $8(34.7 \%)$ were on the second year, $6(26 \%)$ were on the third year and $6(26 \%)$ were on the fourth year. The total correct findings ratios in both groups were significantly lower than the expected. The most frequently recognized ECG patterns were the normal ECG and sinus tachycardia. Respiratory arrhythmia and supraventricular tachycardia were the most frequently misinterpreted ECG patterns.

Conclusion: Duration of ECG training in medical education and pediatric residency should be enhanced and clinical practice should be expanded by the use of different methods to accurate ECG interpretation.

Keywords: Electrocardiography, education, assistant, intern
\end{abstract}

ÖZ

Amaç: Elektrokardiyografi (EKG) kardiyovasküler hastalıkları belirlemede en sık kullanılan yöntemdir. Bu çalışmanın amacı pediatri asistanları ile intörnlerin EKG bilgi düzeylerinin değerlendirilmesi ve EKG eğitiminin tıp eğitimi süresince ne sıkıkta verilmesi gerektiğini saptamaktır.

Gereç ve Yöntemler: Bu çalışma 2009-2010 eğitim yilı içinde Ege Üniversitesi Tıp Fakültesi, Çocuk Hastanesi'nde gerçekleştirildi. Yimi dört pediatri asistanı ve 35 intörn dahil edildi. Her iki gruba da 20 EKG örneğinden oluşan test sunuldu. Bu ön değerlendirmeden sonra, her iki gruba da pediyatrik kardiyoloji bölümünden bir öğretim elemanı tarafından elektrokardiyografi eğitimi verildi. Aynı test eğitimden sonra, birinci ay ve birinci ylıı sonunda katilımcilara sunuldu.

Bulgular: Asistanların 16'sı (\%69,5) kadın, 7'si $(\% 30,5)$ erkek idi. Asistanların 17 'si $(\% 73,9)$ Türkiye vatandaşı idi, 6'sı $(\% 26,1)$ yabancı uyruklu idi. Asistanların 3’ü (\%13) 1. yll, 8'i (\%34,7) 2. yıl, 6'sı (\%26) 3. yıl, 6'sı (\%26) 4. yıl asistanı idi. Her iki grupta da toplam bulguları bilme oranı beklenenden daha düşüktü. En sık tanınan EKG örneği, normal EKG ve sinüs taşikardisi idi. Solunumsal aritmi ve supraventriküler taşikardi en sık yanlış yorumlanan EKG örnekleri idi.

Sonuç: Tıp eğitimi ve uzmanlık eğitimi süresince EKG eğitimine ayrılan süre arttırılmalı, EKG'nin doğru yorumlanabilmesi için klinik uygulamalar yanında EKG eğitiminde farklı metotların denenmesi faydalı olacaktır. Anahtar Kelimeler: Elektrokardiyografi, eğitim, asistan, intörn 


\section{Introduction}

Electrocardiography (ECG) is commonly used in everyday clinical practice and is the most preferred method for the diagnosis of cardiovascular disease (1). As it is available nearly in all centers, not invasive nor expensive, and provides fast and accurate diagnostic results, ECG still remains the most frequently used method in the evaluation of the patients presenting with chest pain, palpitation and syncope, and in the identification of the cause of murmur detected on physical examination by the primary care physicians, emergency physicians and cardiologists (2). Rapid and accurate interpretation of ECG can be lifesaving in many cardiovascular diseases (e.g. ventricular tachycardia, ventricular fibrillationsupraventricular tachycardia, atrioventricular block, long QT syndrome, myocard ischemia-infarction etc.). Therefore, not only the emergency physicians and cardiologists but all physicians should be acquainted with the basic features of ECG. Physicians should be able to interpret ECG rapidly and accurately as this prevents unnecessary examinations and cardiology consultation (3).

The aim of this study is to assess the ECG knowledge levels of pediatric physician assistants and interns, to determine whether there is a difference between ECG knowledge levels of pediatric physician assistants and interns, to identify the knowledge levels of both groups after training and its permanency, and to determine how often ECG should be taught during medical education.

\section{Materials and Methods}

The study was conducted at Ege University Faculty of Medicine, Department of Child Health and Diseases in the 2009-2010 academic years. Twenty-four pediatric residents and 35 interns receiving pediatric rotation were included in the study. Trainings and assessments of assistants and interns were done in two separate groups. A test consisting of 20 ECG patterns was applied to both groups at different times. Together with ECG patterns, only the ages of the patients were indicated; additional clinical information was not provided. Respondents were asked to recognize a total of 30 findings in 20 ECG patterns. For each ECG pattern, respondents were given one minute to decide whether the ECG was normal and if not, to define the all all the abnormal findings. Following a 20-minute evaluation before training, both groups received a 150-minute basic electrocardiography education at different times by a lecturer from the pediatric cardiology department. At the end of the training, the respondents were asked to evaluate the duration and adequacy of the training, competence of the lecturer, and whether the ECG patterns and the physical conditions were sufficient via a questionnaire. In the second part of the same questionnaire, the participants were asked to reply to the questions about their personal information (age, grade, school etc.), whether they had received ECG training during medical education and pediatric cardiology rotation, or if they had conducted a special study of ECG in the past years.

The test consisting of the same questions was applied to both groups before the training, soon after the training, 1 month and 1 year after the training at different times. While evaluating the results, as well as the correct answer rates, some specific ECG patterns (e.g. sinus tachycardia, supraventricular tachycardia (SVT), long QT) were also considered.

\section{Statistical Analysis}

The data were analyzed using SPSS 15.0 (Statistical Package for Social Sciences for Windows) program. Result parameters of the assistant and intern group were expressed as " \pm " standard deviation. Chi-square test was used for the comparisons. $P$ value of less than 0.05 was considered statistically significant.

\section{Results}

Of the assistants, 16 (69.5\%) were female and 7 $(30.5 \%)$ were male. On the other hand, there were 10 (29.4\%) female and 24 (70.6\%) male interns. Seventeen (73.9\%) assistants were citizens of the Turkish Republic and $6(26.1 \%)$ were of foreign nationalities. The number of foreigners in the intern group was only 1 (2.9\%). Three $(13 \%)$ assistants were first, eight $(34.7 \%)$ were second, six $(26 \%)$ were third and six $(26 \%)$ were fourth graders. Seven (30.4\%) assistants were graduates of Ege University Faculty of Medicine; sixteen (69.6\%) were from other medical schools and 2 (8.6\%) were from medical schools abroad. Seven (30.4\%) assistants had been on cardiology rotation and 2 assistants (8.69\%) had conducted a recent study on ECG. On the other hand, twenty-four (73.5\%) interns had conducted a recent study on ECG. Of the assistants, 12 (52.1\%), 6 (26\%) and 5 (21.7\%) had received training on ECG during their education in medicine faculty once, twice and three times, respectively. Interns from Ege university had received training on ECG four times during their education (Table I).

The ratios of recognizing the correct findings in assistants and interns before training were $24.2 \%$ and $17.18 \%$, respectively. These values after training, one month after training and one year after training were $38.5 \%$ and $41.8 \% ; 33.4 \%$ and $42.18 \% ; 32.7 \%$ and $34.37 \%$, respectively (Table II). No statistically significant differences were observed between the two groups with respect to the pre-test and post-test results (in the first month) (p>0.05). The most frequently recognized ECG pattern was normal ECG (in assistants, $60.8 \%$ before the training and $78 \%$ one year after the training; and in interns $52.9 \%$ before the training and $52.4 \%$ one year after the training). Statistically significant difference was observed between the two groups on the posttest in the $12^{\text {th }}$ month $(p<0.05)$. While the ratio of recognizing SVT was similar in both groups before the training, significantly higher rates were observed in assistants in comparison to interns in the 
other sessions. Assessment performed one year after the training revealed statistically significant differences between the two groups $(p<0.05)$. The ratio of recognizing respiratory sinus arrhythmia was significantly lower in both groups than expected. The ratios of recognizing the respiratory sinus arrhythmia in assistants and interns

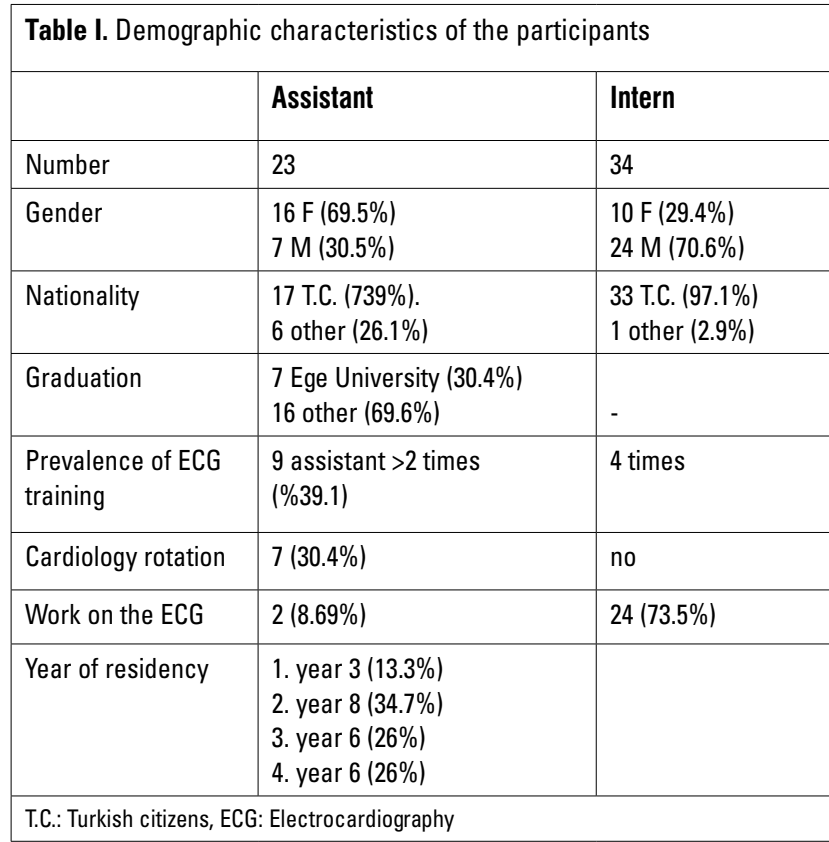

Table II. A comparison in terms of knowing the total electrocardiography findings of assistants and interns

\begin{tabular}{|l|l|l|l|l|}
\hline & Pre-training & Post-training & 1. month & 1. year \\
\hline Assistants & $7.26 \pm 3.79$ & $12.34 \pm 3.5$ & $10.69 \pm 4.69$ & $10.27 \pm 3.1$ \\
& $24.2 \%$ & $38.5 \%$ & $33.4 \%$ & $32.70 \%$ \\
\hline Interns & $5.5 \pm 2.96$ & $13.29 \pm 3.34$ & $13.5 \pm 4.3$ & $11 \pm 3.6$ \\
& $17.18 \%$ & $41.8 \%$ & $42.18 \%$ & $34.7 \%$ \\
\hline$p$ value & $p<0.05$ & $p>0.05$ & $p<0.05$ & $p<0.05$ \\
\hline
\end{tabular}

before the training were $8.6 \%$ and $5.8 \%$. These values were $17.3 \%$ and $11.7 \%, 13 \%$ and $5.8 \%, 17.3 \%$ and $8.8 \%$ soon after the training, in the first month and in the first year, respectively. Statistically significant differences were observed between the two groups in the assessment performed one year after the training $(p<0.05)$. The ratio of recognizing the sinus tachycardia was lower than expected (below $10 \%$ in both groups) and the highest rates $13 \%$ in assistants and $20 \%$ in interns) were observed only in the session following the training. However, it decreased below $10 \%$ in the other sessions. Again, statistically significant differences were observed between the two groups in the assessment performed one year after the training $(p<0.05)$. We observed that approximately one-fifth of the assistants and nearly half of the interns recognized long QT before training but the rates were $52.1 \%$ and $26 \%$ for assistants and interns respectively after the training $(30.4 \%$ and $41 \%$ in the first month, 43,4 and $31.2 \%$ in the assessment one year after the training). Statistically significant difference was observed between the two groups in the assessment performed one year after the training $(p<0.05)$ (Table III). The ratio of recognizing the findings among graduates of Ege university were found to be higher than those of other universities. There was no statistically significant difference between the graduates of Ege University and those of other universities with respect to the ratio of recognizing the findings in the post-tests $(p>0.05)$. Total finding ratios of the assistants who had received cardiology rotation were significantly higher than those who had not (before training, after training and in the first month) $(p<0.05)$. But this difference was not significant in the assessment performed one year after the training $(p>0.05)$. In the first three sessions, as the year in assistantship increased, the ratio of recognizing the findings increased, too. At the end of the one year, these ratios were $15 \%$ in the first grade assistants and were similar in the second, third and fourth grade assistants (30\%). No statistically significant difference was observed with respect to the grade $(p<0.05)$ (Table IV).

Table III. The comparison in terms of knowing the electrocardiography findings of assistants and interns

\begin{tabular}{|c|c|c|c|c|c|c|c|c|c|c|}
\hline & Assistants & & & & & Interns & & & & \\
\hline & Normal ECG & $\begin{array}{l}\text { Respiratory } \\
\text { arrhythmia }\end{array}$ & SVT & Sinus tachycardia & LongQT & $\begin{array}{l}\text { Normal } \\
\text { ECG }\end{array}$ & $\begin{array}{l}\text { Respiratory } \\
\text { arrhythmia }\end{array}$ & SVT & $\begin{array}{l}\text { Sinus } \\
\text { tachycardia }\end{array}$ & LongQT \\
\hline Pre-training $\%$ & $\begin{array}{l}14 \\
60.8\end{array}$ & $\begin{array}{l}2 \\
8.6\end{array}$ & $\begin{array}{l}6 \\
26\end{array}$ & $\begin{array}{l}1 \\
4.3\end{array}$ & $\begin{array}{l}5 \\
21.7\end{array}$ & $\begin{array}{l}18 \\
52.9\end{array}$ & & $\begin{array}{l}8 \\
23\end{array}$ & $\begin{array}{l}1 \\
2.9\end{array}$ & $\begin{array}{l}16 \\
47\end{array}$ \\
\hline Post-training \% & $\begin{array}{l}17 \\
73.9\end{array}$ & $\begin{array}{l}4 \\
17.3\end{array}$ & $\begin{array}{l}10 \\
43.4\end{array}$ & $\begin{array}{l}3 \\
13\end{array}$ & $\begin{array}{l}12 \\
52.1\end{array}$ & $\begin{array}{l}23 \\
67.6\end{array}$ & $\begin{array}{l}4 \\
11.7\end{array}$ & $\begin{array}{l}3 \\
8\end{array}$ & $\begin{array}{l}7 \\
20\end{array}$ & $\begin{array}{l}9 \\
26\end{array}$ \\
\hline 1. month $\%$ & $\begin{array}{l}17 \\
73.9\end{array}$ & $\begin{array}{l}3 \\
13\end{array}$ & $\begin{array}{l}12 \\
52.1\end{array}$ & $\begin{array}{l}1 \\
4.3\end{array}$ & $\begin{array}{l}7 \\
30.4\end{array}$ & $\begin{array}{l}21 \\
61.7\end{array}$ & $\begin{array}{l}2 \\
5.8\end{array}$ & $\begin{array}{l}2 \\
5\end{array}$ & $\begin{array}{l}2 \\
5.8\end{array}$ & $\begin{array}{l}14 \\
41.1\end{array}$ \\
\hline 1. year $\%$ & $\begin{array}{l}18 \\
78\end{array}$ & $\begin{array}{l}4 \\
17.3\end{array}$ & $\begin{array}{l}14 \\
60.8\end{array}$ & $\begin{array}{l}2 \\
5.8\end{array}$ & $\begin{array}{l}10 \\
43.4\end{array}$ & $\begin{array}{l}17 \\
52\end{array}$ & $\begin{array}{l}3 \\
8.8\end{array}$ & $\begin{array}{l}7 \\
20\end{array}$ & $\begin{array}{l}2 \\
5.8\end{array}$ & $\begin{array}{l}11 \\
31.2\end{array}$ \\
\hline
\end{tabular}

ECG: Electrocardiography, SVT: Supraventricular tachycardia 


\begin{tabular}{|c|c|c|c|c|}
\hline Assistants & Pre-training & Post-training & 1. month & 1. year \\
\hline 1. year & $\begin{array}{l}5 \pm 1.73 \\
16.6 \%\end{array}$ & $\begin{array}{l}9.6 \pm 2 \\
30.2 \%\end{array}$ & $\begin{array}{l}4.3 \pm 5.13 \\
13.5 \%\end{array}$ & $\begin{array}{l}5 \pm 5 \\
15.6 \%\end{array}$ \\
\hline 2. year & $\begin{array}{l}6.1 \pm 3.5 \\
20.4 \%\end{array}$ & $\begin{array}{l}12.2 \pm 3.32 \\
38.2 \%\end{array}$ & $\begin{array}{l}11.25 \pm 3.73 \\
35.1 \%\end{array}$ & $\begin{array}{l}10.8 \pm 2.10 \\
33.9 \%\end{array}$ \\
\hline 3. year & $\begin{array}{l}7.5 \pm 4.84 \\
25.0 \%\end{array}$ & $\begin{array}{l}11.8 \pm 4.7 \\
36.9 \%\end{array}$ & $\begin{array}{l}10.6 \pm 5 \\
32.6 \%\end{array}$ & $\begin{array}{l}10.5 \pm 2.73 \\
32.8 \%\end{array}$ \\
\hline 4. year & $\begin{array}{l}9.6 \pm 3 \\
32.21 \%\end{array}$ & $\begin{array}{l}14.3 \pm 2.58 \\
44.7 \%\end{array}$ & $\begin{array}{l}13.1 \pm 2.99 \\
41.1 \%\end{array}$ & $\begin{array}{l}10.16 \pm 4.53 \\
31.7 \%\end{array}$ \\
\hline
\end{tabular}

Discussion

ECG is the most commonly used method for determining cardiovascular disease (4). In order to make a rapid and accurate decision in some diseases such as myocard ischemia, severe electrolyte imbalance or life-threatening serious arrhythmias, clinicians should receive ECG training during their medical education (5).

As in abroad, pediatric cardiologists are not available in pediatric emergency services in our country; ECGs are primarily interpreted by general practitioners and pediatricians, and if necessary, pediatric cardiology consultation is requested. Performing necessary interventions and the accurate interpretation of ECG is crucial. However, Horton et al. study has shown a difference of $24 \%$ between the ECG interpretation of general pediatricians and that of pediatric cardiologists (6). In a prospective study conducted at University of Colorado, Children's Hospital between 1999 and 2002, it was shown that ECG was requested from 1501 patients in the pediatric emergency service and $87 \%$ of ECGs were interpreted similarly by general pediatricians and pediatric cardiologists. (7).

In Snyder et al.'s (3) study of 78 interns and 54 assistants from pediatric residency program in the United States, a test involving 17 ECG patterns was given to the participants in four different sessions. The same ECG samples were used in each session. The results revealed that the total finding ratio was $60 \%$ in pediatric residents and $55 \%$ in interns. They observed an increase in the scores with ECG training but there was no significant difference between the two groups. Right and left atrial enlargement, WPW and sinus arrhythmia were the most misinterpreted cases $160 \%$ in assistants and $>80 \%$ in interns). It was also determined that sinus arrhythmia, which is quite common in clinical practice, was misinterpreted by more than two-thirds of the participants and mistaken for AV block sinus bradycardia and premature atrial contractions.

In our study, total finding ratio in assistants was higher before the training. Both groups showed a significant increase after the training but a gradual decrease was observed in the 1- month and 1-year post-tests. Having an intern group receiving emergency and cardiology rotation and thus becoming experienced in ECG interpretation was thought to be an important factor influencing the increase in the interns' scores. While an improvement in interpreting the ECG was observed in assistants in the early period after training, we saw lower correct answer rates than expected in the following sessions. This may be attributed to the fact that the assistants have not conducted a special study on ECG.

Our study revealed that sinus tachycardia was the most common misinterpreted ECG sample. Such lower rates can be due to the fact that the participants interpreted the ECG without considering the fact that pediatric ECG may vary by age, as in sinus arrhythmia. At the end of the initial assessment, the basic features of ECG interpretation were taught and the variability of pediatric ECG was emphasized. That is why there is an increase in participants' scores after the training. As well as sinus tachycardia, having pulmonale and right atrial dilatation in ECG pattern might have prevented the recognition of sinus tachycardia by the participants as they did not consider the ages of the cases. However, ECG should be interpreted as a whole by taking the basic features into consideration.

As in Snyder et al. (3) study, sinus arrhythmia was misinterpreted by most of the participants in our study and was found to be the second most frequently misinterpreted ECG pattern. In both groups, sinus arrhythmia was mistaken for premature atrial contractions and sinus bradycardia, or considered as normal. This error can be due to the fact that the participants searched for specific pathologies without considering the basic steps in ECG interpretation such as rhythm, speed, p wave (amplitude and duration) and PR and $R R$ intervals.

SVT was the third most frequently misinterpreted ECG pattern. SVT was most frequently mistaken for ventricular tachycardia and sinus tachycardia by the interns. Having higher ratio of recognizing SVT in the assistant group than that in the interns can be expressed by the fact that SVT is the second most frequent arrhythmia after sinus tachycardia in pediatric practice. Because of the fact that interns have a relatively shorter pediatric emergency rotation and therefore they encounter a limited number of cases, and that the probability of encountering rhythm disturbance, namely atrial fibrillation, ventricular tachycardia and ventricular fibrillation in emergency and cardiology rotations is high, the ratio of recognizing SVT was lower in the intern group. In a study of Eslava et al. (8), they showed that internal medicine residents could correctly interpret the $43 \%$ of ECG samples. In our study in both groups, normal ECG was frequently interpreted accurately. Two out of 20 ECG patterns were normal. Interpreting both the patterns as normal means that participants recognized normal ECG. The ratio of recognizing normal ECG in assistants was higher than that in interns in four tests and showed a decline in interns. Basic features of ECG vary by age, gender and race. Since pediatric residents look after only pediatric patients, they pay more attention to these changes in interpreting the ECG. This might explain the higher ratios in assistants. 
Long QT syndrome must be taken into consideration in interpreting the ECG. In Lever et al. (9) study, which involves fourth grade students from Auckland and Otago Universities (New Zealand) Medical schools, and first and second grade family physician assistants from Wellington hospital, the ratios of recognizing miyocard ischemia were $87 \%$ and $93 \%$, respectively, while this ratio was $7 \%$ for long OT. In our study, the ratio of recognizing QT was two-fold higher in interns than that in assistants but became reversed after the training (at the end of one year, $43.4 \%$ in assistants and $31.2 \%$ in interns). Both long QT and ventricular premature contraction were present in the ECG pattern. Post-test evaluation revealed that most of the interns recognized ventricular premature contraction but the ratio for long QT was only $26 \%$.

In their study conducted at Johns Hopkins Children's Hospital, Crocetti and Thompson (2) enrolled 46 pediatric physician assistants, and the participants were asked to specify the ECG findings of 10 patients. Study results showed that as the year in residency increases, the ratio of recognizing the correct findings increases too. Sixtyone percent of the participating assistants had received cardiology rotation and the ratio of correct findings in the cardiology rotation-received group was higher than that in the other group (2). In our study, the ratio of correct findings in assistants who had received cardiology rotation was higher not in the first three tests, but similar in the test applied one year after the training. And similarly, before the training. As the year in assistantship increases, the ratio of correct findings increases too. There was an increase in the total correct findings in the assistant group after the training. The similar ratios in the second, third and fourth grade assistants in the post-test ( 1 year after the training) may be due to the fact that the second and third grade assistants received cardiology rotation.

In conclusion, it was observed that the correct finding ratio after the training was quite lower than expected and that it increased after the training but showed a decrease again in the assessments in the first month and one year after the training. Considering the above-mentioned results, we are of the opinion that the duration of ECG training in medical education and pediatric residency should be enhanced, theoretical training should be reinforced by clinical practice and the use of different methods should be involved in ECG training in order to achieve faster and more accurate ECG interpretation.

\section{Authorship Contributions}

Ethics Committee Approval: The study were approved by the Ege University of Local Ethics Committee, Informed Consent: Consent form was filled out by all participants, Concept: Gülhadiye Avcu, Ertürk Levent, Design: Gülhadiye Avcu, Ertürk Levent, Data Collection or Processing: Gülhadiye Avcu, Ertürk Levent, Analysis or Interpretation: Gülhadiye Avcu, Ertürk Levent, Literature Search: Gülhadiye Avcu, Writing: Gülhadiye Avcu, Peer-review: External and Internal peer-reviewed, Conflict of Interest: No conflict of interest was declared by the authors, Financial Disclosure: The authors declared that this study has received no financial support.

\section{References}

1. Boltri $J M$, Hash RB, Vogel RL, Are family practice residents able to interpret electrocardiograms? Adv Health Sci Educ Theory Pract 2003; 8; 149-53.

2. Crocetti $M$, Thompson $R$, Electrocardiogram interpretation skills in pediatric residents. Ann Pediatr Cardiol 2010; 3: 3-7.

3. Snyder CS, Bricker JT, Fenrich AL, et al. Can pediatric residents interpret electrocardiograms? Pediatr Cardiol 2005; 26: 396-9.

4. Trzeciak S, Erickson T, Bunney EB, et al. Variation in patient management based on ECG interpretation by emergency medicine and internal medicine residents. Am J Emergency Med 2002 ; 20: 188-95.

5. Hoyle RJ, Walker KJ, Thomson G, Bailet M. Accuracy of electrocardiogram interpretation improves with emergency medicine training. Emerg Med Australas 2007; 19: 143-50.

6. Horton LA, Mosee S, Brenner J. Use of the electrocardiogram in a pediatric emergency department. Arch Pediatr Adolesc Med 1994; 148: 184-8.

7. Wathen JE, Rewers AB, Yetman AT, Schaffer MS. Accuracy of ECG interpretation in the pediatric emergency department. Ann Emerg Med 2005; 46: 507-11.

8. Eslava D, Dhillon S, Berger J, Homel P, Bergmann S. Interpretation of electrocardiograms by first-year residents: the need for change. J Electrocardiol 2009; 42: 693-7.

9. Lever NA, Larsen PD, Dawes M, Wong A, Harding SA. Are our medical graduates in New Zealand safe and accurate in ECG interpretation? N Z Med J 2009; 122: 9-15. 